Jurnal Mahasiswa BK An-Nur : Berbeda, Bermakna, Mulia

Volume 7 Nomor 2 Tahun 2021

Tersedia Online: https://ojs.uniska-bjm.ac.id/index.php/AN-NUR

p-ISSN. 2460-9722 | e-ISSN. 2622-8297

\title{
MOTIVASI INSTRINSIK, DUKUNGAN SOSIAL DAN PROKRASTINASI AKADEMIK MAHASISWA INSTITUT AGAMA ISLAM NEGERI KERINCI
}

\author{
Harmalis $^{1}$, Nuzmi Sasferi ${ }^{2}$, Naidarti ${ }^{3}$, Dosi Juliawati ${ }^{4}$, Hengki Yandri ${ }^{5}$ \\ 1,2,3,4,5 Institut Agama Islam Negeri Kerinci \\ E-mail: hengki@konselor.org
}

\begin{abstract}
ABSTRAK
Penelitian ini bertujuan untuk menganalisis hubungan negatif dukungan sosial dan motivasi intrinsik dengan prokrastinasi akademik pada mahasiswa Institut Agama Islam Negeri Kerinci. Penelitian ini merupakan jenis penelitian deskriptif kuantitatif dengan pendekatan korelasional. Jumlah sampel penelitian ini sebanyak 72 mahasiswa yang diambil dari mahasiswa jurusan Bimbingan dan Konseling Pendidikan Islam. Adapun instrumen yang digunakan untuk mengumpulkan data dalam penelitian ini adalah skala prokrastinasi akademik, dukungan sosial, dan motivasi intrinsik. Data tersebut diolah dengan menggunakan metode analisis Regresi Berganda dengan bantuan komputer melalui aplikasi SPSS Versi 17. Hasil dari penelitian menunjukkan nilai koefesien korelasi (R) antara dukungan sosial dan motivasi intrinsik dengan prokrastinasi akademik sebesar 0,826 dengan $\mathrm{P}=0,000<0,05$. Hal ini menunjukkan bahwa terjadi hubungan yang kuat antara dukungan sosial dan motivasi intrinsik dengan prokrastinasi akademik pada mahasiswa jurusan Bimbingan dan Konseling Pendidikan Islam Institut Agama Islam Negeri Kerinci. Nilai R2 (R Square) sebesar 0,682, artinya bahwa persentase sumbangan antara dukungan sosial dan motivasi intrinsik dengan prokrastinasi akademik adalah sebesar $68,2 \%$.
\end{abstract}

Kata Kunci: dukungan sosial, motivasi intrinsik, prokrastinasi akademik

\begin{abstract}
This study aims to analyze hubungan negatif social support and intrinsic motivation with academic procrastination in students of the Institut Agama Islam Negeri Kerinci. This research is a type of quantitative descriptive research with a correlational approach. A sample of this study as many as 72 students taken from students majoring in Bimbingan dan Konseling Pendidikan Islam. The instruments used to collect data in this study are the scale of academic procrastination, social support, and intrinsic motivation. The data is processed using multiple regression analysis methods with the help of a computer through spss application Version 17. The results showed a correlation coeffesient value $(\mathrm{R})$ between social support and intrinsic motivation with academic procrastination of 0.826 with $\mathrm{P}=0.000<0.05$. This shows that there is a strong link between social support and intrinsic motivation with academic procrastination in students majoring in Bimbingan dan Konseling Pendidikan Islam Institut Agama Islam Negeri Kerinci . The R2 (R Square) value is 0.682, meaning that the percentage of donations between social support and intrinsic motivation with academic procrastination is $68.2 \%$.
\end{abstract}

Keywords: social support, intrinsic motivation, academic procrastination

Dipublikasikan oleh :

UPT Publikasi dan Pengelolaan Jurnal

Universitas Islam Kalimantan Muhammad Arsyad Al-Banjari Banjarmasin 
Harmalis., Sasferi, N., Naidarti., Juliawati, D., Yandri, $H$. Jurnal Mahasiswa BK An-Nur : Berbeda, Bermakna, Mulia Volume 7 Nomor 2 Tahun 2021

Tersedia Online: https://ojs.uniska-bjm.ac.id/index.php/AN-NUR p-ISSN. 2460-9722 | e-ISSN. 2622-8297

\section{PENDAHULUAN}

Generasi muda memiliki peranan penting dalam meningkatkan dan membangun pendidikan Indonesia, hal ini dapat dilihat dari setiap aktivitas generasi muda dalam mengembangkan dan meningkatkan Sumber Daya Manusianya. Mahasiswa merupakan generasi muda yang memiliki energi berlimpah sehingga dapat mengembangkan dan meningkatkan Sumber Daya Manusia menjadi lebih baik (Yandri \& Juliawati, 2018). Kegiatan belajar dan pengerjaan tugas kuliah yang diberikan oleh dosen merupakan suatu rutinitas yang mesti dilalui dan dilakukan oleh setiap mahasiswa, namun sering kali kita melihat dan mendengar bahwa sebagian mahasiswa terlambat dalam mengerjakan tugas tersebut, keterlambatan dalam mengerjakan tugas merupakan salah satu bentuk perilaku menunda atau yang dikenal dengan istilah prokrastinasi (Juliawati \& Yandri, 2018)

Prokrastinasi adalah menunda dengan sengaja kegiatan yang diinginkan walaupun individu mengetahui bahwa perilaku penundaanya tersebut dapat menghasilkan dampak buruk (Steel, 2007; Juliawati, 2014). Kemudian Brown \& Holzman mengatakan bahwa Prokrastinasi merupakan suatu kecenderungan menunda-nunda penyelesaian suatu tugas atau pekerjaan (Rizvi et. al., 1997). Dapat dipahami bahwa prokrastinasi adalah suatu bentuk perilaku yang dengan sengaja menunda-nunda menyelesaikan tugas atau pekerjaan tertentu.

Peterson mengatakan bahwa seseorang dapat melakukan prokrastinasi hanya pada hal-hal tertentu saja atau pada semua hal (Rizvi et. al., 1997). Jenisjenis tugas yang sering ditunda oleh prokrastinator adalah tugas pembuatan keputusan, tugas rumah rangga, tugas aktivitas akademik, pekerjaan kantor, dan lainnya. Prokrastinasi terbagi menjadi dua jenis yaitu (1) Functional Procrastination, yaitu penundaan mengerjakan tugas yang bertujuan untuk memperoleh informasi yang lebih lengkap dan akurat ; (2) Disfunction Procrastination, yaitu penundaan yang tidak bertujuan, berakibat jelek, dan bermasalah (Ferrari, et al, 1995). Prokrastinsi akademik dan non akademik sering menjadi istilah yang digunakan oleh para ahli untuk membagi jenis-jenis tugas yang ditunda oleh prokrastinator, seperti tugas pembuatan keputusan, tugas rumah rangga, tugas aktivitas akademik, dan pekerjaan kantor (Ghufron \& Risnawati, 2010).

Prokrastinasi akademik adalah jenis penundaan yang dilakukan pada jenis tugas formal yang berhubungan dengan akademik, seperti tugas sekolah, kuliah, dan kursus. Prokrastinasi non akademik adalah penundaan yang dilakukan pada jenis tugas non formal atau tugas yang berhubungan dengan kehidupan sehari-hari, seperti tugas rumah tangga, tugas sosial, tugas kantor dan sebagainya (Ferrari, 1995). Dapat dipahami prokrastinasi akademik merupakan suatu kecenderungan penundaan yang dilakukan pada tugas formal seperti tugas kuliah dan tugas sekolah yang berhubungan dengan akademik.

Millgram et al., mengatakan salah satu faktor internal yang dapat mempengaruhi prokrastinasi adalah faktor psikologis (Rizvi et. al., 1997). Faktor psikologis merupakan faktor yang berasal dari dalam diri individu yang berkaitan dengan aspek-aspek psikis seperti kecerdasan emosi dan motivasi (Faiz, et al., 2019; Ulandari \& Juliawati, 2019). Motivasi pada seseorang berfungsi untuk mendorong seseroang untuk berbuat dan bereaksi (Chaplin, 2002), motivasi sebagai pendorong yang mengubah energi dalam diri seseorang ke dalam bentuk aktivitas nyata untuk mencapai tujuan tertentu (Djamarah, 2002). Selanjutnya menurut MC. Donald motivasi adalah suatu perubahan energi di dalam pribadi seseorang yang ditandai timbulnya afektif (perasaan) dan reaksi untuk mencapai tujuan (Hamalik, 1992). Dapat dipahami bahwa definisi motivasi adalah Sesuatu yang dapat mendorong terjadinya perubahan energi di dalam diri individu yang diiringi dengan perasaan dan reaksi untuk melakukan aktivitas nyata dalam mencapai tujuan tertentu.

Motivasi intrinsik adalah dorongan yang berasal dari dalam diri individu untuk mencapai tujuan tertentu. Briordy mengatakan besarnya motivasi intrinsik yang dimiliki individu dapat mempengaruhi prokrastinasi secara negatif. Semakin tinggi motivasi intrinsik yang dimiliki individu ketika menghadapi tugas, maka akan semakin rendah kecenderunganya untuk prokrastinasi akademik. Sebaliknya semakin rendah motivasi intrinsik yang dimiliki individu ketika menghadapi tugas, maka akan semakin tinggi kecenderunganya untuk prokrastinasi akademik (Ferrari, 1991).

Dapat dipahami bahwa motivasi intrinsik memiliki kotribusi terhadap prokrastinasi secara negatif dalam menghadapi tugas mahasiswa. Hal ini sejalan dengan hasil penelitian tentang hubungan antara motivasi belajar dengan prokrastinasi akademik siswa di SMP N 25 Padang. Hasil penelitianya menunjukkan sebesar -0,636 dengan signifikansi 0,000 yang berada pada ketagori cukup, yang bermakna bahwa motivasi belajar memiliki hubungan 
Harmalis., Sasferi, N., Naidarti., Juliawati, D., Yandri, $H$. Jurnal Mahasiswa BK An-Nur : Berbeda, Bermakna, Mulia Volume 7 Nomor 2 Tahun 2021

Tersedia Online: https://ojs.uniska-bjm.ac.id/index.php/AN-NUR p-ISSN. 2460-9722 | e-ISSN. 2622-8297

yang singnifikan secara negatif dengan prokrastinasi akademik siswa (Nitami et al., 2015). Dengan kata lain semakin tinggi motivasi belajar siswa maka prokrastinasi akademik siswa semakin rendah. Sebaliknya semakin rendah motivasi belajar siswa maka semakin tinggi prokrastinasi akademiknya.

Salah satu dari faktor eksternal yang dapat mempengaruhi prokrastinasi akademik adalah dukungan sosial seperti dukungan sosial dari orang tua dan dukungan sosial dari teman sebaya (Ghufron, 2003). Artinya dukungan sosial dari orang-orang yang berada di sekitar individu memiliki hubungan negatif dengan perilaku prokrastinasi individu terhadap tugasnya. Hal ini sejalan dengan hasil penlitian tentang hubungan antara dukungan sosial teman sebaya dengan prokrastinasi menghafal al-qur'an pada santri di pondok pesantren modern islam assalaam surakarta. Hasil penelitiannya menunjukkan nilai rxy $=-, 335(\mathrm{p}<0,05)$ yang berarti adanya korelasi negatif yang signifikan antara dukungan sosial teman sebaya dengan prokrastinasi menghafal Al-Qur'an (Wiyarti \& Setyawan, 2017). Artinya semakin tinggi dukungan sosial teman sebaya maka semakin rendah prokrastinasi menghafal Al-Qur'an. Sebaliknya, semakin rendah dukungan sosial teman sebaya maka semakin tinggi prokrastinasi menghafal Al-Qur'an.

Sarason \& Sarason mengatakan bahwa dukungan sosial adalah dukungan yang didapat dari keakraban (teman, keluarga, anak ataupun orang lain) berupa pemberian informasi, nasehat verbal ataupun nonverbal dan bantuan nyata atau tidak nyata, tindakan yang bermanfaat sosial dan efek perilaku bagi penerima yang akan melindungi diri dari perilaku negatif (Marni \& Yuniawati, 2015). Selanjutnya menurut Rook dukungan sosial merupakan salah satu fungsi dari ikatan sosial, dan ikatan-ikatan sosial tersebut menggambarkan tingkat kualitas umum dari hubungan interpersonal (Kumalasari \& Ahyani, 2012). Ikatan dan persahabatan dengan orang lain dianggap sebagai aspek yang memberikan kepuasan secara emosional dalam kehidupan individu (Sartika \& Yandri, 2019). Dapat dipahami bahwa dukungan sosial adalah dukungan yang didapat dari ikatan sosial individu dengan orang lain berupa pemberian informasi, nasehat verbal ataupun nonverbal dan bantuan nyata atau tidak nyata, tindakan yang bermanfaat sosial dan efek perilaku bagi penerima yang akan melindungi diri dari perilaku negatif dan dapat memberikan kepuasan secara emosional dalam kehidupan individu.

Dapat dipahami bahwa dukungan sosial memiliki peran penting dalam memberikan kontribusi negatif terhadap prokrastinasi akademik, sehingga dengan semakin tinggi dukungan sosial dari orangorang sekitar mahasiswa, maka akan semakin rendah prokrastinasi akademik mahasiswa, dan begitu pula sebaliknya semakin rendah dukungan sosial dari orang-orang sekitar mahasiswa, maka akan semakin tinggi prokrastinasi akademik mahasiswa.

Pendidikan formal memiliki peranan penting untuk membentuk dan mengembangkan akhlak dan perilaku disiplin mahasiswa dalam memenuhi tugas dan kewajiban nya. Melalui pendidikan formal mahasiswa dapat belajar pengetahuan, teknologi, pengalaman, dan nilai-nilai norma yang baik terutama yang berhubungan dengan keteraturan dan ketepatan waktu dalam memenuhi tanggung jawab sebagai seorang mahasiswa (Juliawati, 2017). Sehingga dengan demikian dapat dipahami bahwa mahasiswa yang sedang menempuh pendidikan tinggi tentu memiliki keteraturan dan ketepatan waktu dalam menghadapi tugas yang telah diberikan oleh dosen atau dengan kata lain menunda-nunda pengerjaan tugas tersebut.

Pada tanggal 11, 12 dan 13 Maret 2019 penulis telah melakukan survey di Jurusan Bimbingan dan Konseling Pendidikan Islam (BKPI) Institut Agama Islam Negeri (IAIN) Kerinci dengan jumlah sampel sebanyak 100 orang mahasiswa. Pada hari pertama, kedua dan ketiga penulis melakukan observasi tentang perilaku prokrastinasi akademik, di antaranya yang berhubungan dengan ketepatan waktu dan keterlambatan dalam mengerjakan dan menyelesaikan tugas yang diberikan oleh dosen dan diperoleh hasil observasi perilaku prokratinasi akademik mahasiswa Jurusan BKPI IAIN Kerinci adalah 60 mahasiswa memiliki perilaku prokrastinasi akademik yang tinggi dan sisanya 40 mahasiswa memiliki perilaku prokrastinasi akademik rendah. Hasil observasi tersebut menunjukkan $40 \%$ mahasiswa yang memiliki perilaku prokrastinasi akademik yang rendah dan sisanya $60 \%$ mahasiswa yang memiliki perilaku prokrastinasi akademik yang tinggi. Indikasi perilaku prokrastinasi akademik mahasiswa yang tinggi di antaranya: Mahasiswa menunda untuk memulai dan menyelesaikan tugas, keterlambatan dalam mengerjakan tugas, kesenjangan waktu antara rencana dan kinerja aktual, dan melakukan aktivitas lain yang lebih menyenangkan dari pada mengerjakan tugas.

Dengan demikian dapat diasumsikan bahwa motivasi intrinsik dan dukungan sosial yang menjadi penyebab sehingga tingginya perilaku prokrastinasi akademik mahasiswa Jurusan BKPI IAIN Kerinci. Sehingga tujuan dari penelitian ini yaitu untuk 
Harmalis., Sasferi, N., Naidarti., Juliawati, D., Yandri, $H$. Jurnal Mahasiswa BK An-Nur : Berbeda, Bermakna, Mulia

Volume 7 Nomor 2 Tahun 2021

Tersedia Online: https://ojs.uniska-bjm.ac.id/index.php/AN-NUR

p-ISSN. 2460-9722 | e-ISSN. 2622-8297

mengungkap kondisi dukungan sosial, motivasi intrinsik dan prokrastinasi akademik mahasiswa, kemudian menguji hubungan dukungan sosial, dan motivasi intrinsik dengan prokrastinasi akademik mahasiswa.

\section{METODE}

Metode Penelitian ini merupakan jenis penelitian deskriptif kuantitatif dengan pendekatan korelasional yang bertujuan untuk menguji hubungan dukungan sosial dan motivasi intrinsik dengan prokrastinasi akademik mahasiswa dengan prosedur analisis statistik. Adapun yang menjadi responden dalam penelitian ini adalah seluruh mahasiswa angkatan 2019 Jurusan BKPI IAIN Kerinci yang berjumlah 72 orang.

Data penelitian dikumpulkan dengan skala prokrastinasi akademik, dukungan sosial, dan motivasi instrinsik yang peneliti kembangkan sendiri berdesarkan teori yang ada. Untuk skala prokrstinasi akademik, peneliti mengambil teori Ferrari dengan aspek-aspek Prokrastinasi Akademik berupa penundaan untuk memulai menyelesaikan tugas, keterlambatan dalam mengerjakan tugas, kesenjangan waktu antara rencana dan kinerja aktual, dan melakukan aktivitas lain yang lebih menyenangkan (Ghufron \& Risnawati, 2010). Selanjutnya skala yang digunakan untuk dukungan sosial berpedoman teori Sarafino dengan aspek-aspek dukungan sosial berupa emosional, penghargaan, instrumental, informasi, dan jaringan (Suryabrata, 2005). Kemudian Skala yang digunakan untuk motivasi intrinsik dikembangkan berdasarkan teori Harackiewicz dan Elliot dengan aspek-aspek motivasi intrinsik yaitu: kesenangan dan ketertarikan aktivitas, kebebasan untuk memilih, dan mengerti akan kemampuan dan penilaian kemampuannya (Elliot et. al., 2000).

Analisis data dilakukan dengan cara mencari rata-rata empiris dan rata-rata hipotetik dari respon subjek penelitian untuk variabel dukungan sosial, motivasi intrinsik, dan prokrastinasi akademik selanjutnya untuk melihat hubungan antar variabel digunakan rumus korealasi dan regresi berganda (Arikunto, 2010)

\section{HASIL DAN PEMBAHASAN \\ Hasil}

Distribusi frekuensi hasil temuan penelitian yang telah dilakukan kepada 72 orang mahasiswa jurusan BKPI IAIN Kerinci yang aktif pada semester ganjil 2019/2020 mengungkapkan bahwa rata-rata dukungan sosial mahasiswa jurusan BKPI IAIN Kerinci berada pada kategori sedang, untuk lebih jelasnya bisa dilihat pada tabel 1 berikut:

Tabel 1. Distribusi Frekuensi Dukungan Sosial Mahasiswa

\begin{tabular}{|c|c|c|c|}
\hline Kategori & Rentang Nilai & $\mathbf{F}$ & Persentase \\
\hline Tinggi & $\geq 102$ & 17 & $25 \%$ \\
\hline Sedang & $81-102$ & 42 & $56,9 \%$ \\
\hline Rendah & $<81$ & 13 & $18,1 \%$ \\
\hline \multicolumn{2}{|c|}{ Jumlah } & 72 & $100 \%$ \\
\hline
\end{tabular}

Dari Tabel 1 dapat diketahui bahwa responden yang memiliki dukungan sosial yang tinggi sebanyak 17 mahasiswa (25,0\%), dukungan sosial sedang sebanyak 42 mahasiswa (56,9\%), dan dukungan sosial rendah sebanya 13 mahasiswa $(18,1 \%)$, secara umum responden dalam penelitian dapat dikatakan memiliki dukungan sosial dalam kategori sedang.

Selanjutnya, hasil pengungkapan data motivasi instrinsik mahasiswa jurusan BKPI IAIN Kerinci ratarata berada pada kategori sedang, untuk gambaran keseluruhan bisa di lihat pada tabel 2 berikut.

Tabel 2. Distribusi Frekuensi Motivasi Instrinsik Mahasiswa

\begin{tabular}{|c|c|c|c|}
\hline Kategori & Rentang Nilai & $\mathbf{F}$ & Persentase \\
\hline Tinggi & $\geq 65$ & 16 & 22,2 \\
\hline Sedang & $51-65$ & 50 & 69,4 \\
\hline Rendah & $<51$ & 6 & 8,3 \\
\hline \multicolumn{2}{|c|}{ Jumlah } & 72 & $100 \%$ \\
\hline
\end{tabular}

Dari Tabel di atas, dapat diketahui bahwa responden yang memiliki motivasi intrinsik yang tinggi sebanyak 16 mahasiswa (22,2\%), motivasi intrinsik sedang sebanyak 50 mahasiswa $(69,4 \%)$, dan motivasi intrinsik rendah sebanyak 6 mahasiswa $(8,3 \%)$, secara umum responden dalam penelitian dapat dikatakan memiliki motivas intrinsik dalam kategori sedang.

Tabel 3. Distribusi Frekuensi Prokrastinasi Akademik Mahasiswa

\begin{tabular}{|c|c|c|c|}
\hline Kategori & Rentang Nilai & $\mathbf{F}$ & Persentase \\
\hline Tinggi & $\geq 83$ & 11 & 15,3 \\
\hline Sedang & $67-83$ & 46 & 63,9 \\
\hline Rendah & $<67$ & 15 & 20,8 \\
\hline \multicolumn{2}{|c|}{ Jumlah } & 72 & $100 \%$ \\
\hline
\end{tabular}


Harmalis., Sasferi, N., Naidarti., Juliawati, D., Yandri, $H$. Jurnal Mahasiswa BK An-Nur : Berbeda, Bermakna, Mulia

Volume 7 Nomor 2 Tahun 2021

Tersedia Online: https://ojs.uniska-bjm.ac.id/index.php/AN-NUR

p-ISSN. 2460-9722 | e-ISSN. 2622-8297

Dari Tabel di atas, dapat diketahui bahwa responden yang memiliki prokrastinasi akademik yang tinggi sebanyak 11 mahasiswa (15,3\%), prokrastinasi akademik sedang sebanyak 46 mahasisiwa $(63,9 \%)$, dan prokrastinasi akademik rendah sebanya 15 mahasiswa $(20,8 \%)$, secara umum responden dalam penelitian dapat dikatakan memiliki prokrastinasi akademik dalam kategori sedang

Tabel 4. Hasil Uji Normalitas

\begin{tabular}{lccc}
\hline \multicolumn{1}{c}{ Variabel } & $\begin{array}{c}\text { Kolmogorov } \\
\text {-Smirnov } Z\end{array}$ & $\begin{array}{c}\text { Asymp.Sig. } \\
\text { (2-tailed) }\end{array}$ & Ket. \\
\hline $\begin{array}{l}\text { Prokrastinasi } \\
\text { Akademik }\end{array}$ & 0,670 & 0,760 & Normal \\
$\begin{array}{l}\text { Dukungan } \\
\text { Sosial } \\
\text { Motivasi }\end{array}$ & 0,734 & 0,655 & Normal \\
Intrinsik & 0,663 & 0,771 & Normal \\
\hline
\end{tabular}

Berdasarkan uraian dalam tabel di atas, diketahui bahwa uji asumsi normalitas terhadap variabel prokrastinasi akademik, dukungan sosial, dan motivasi intrinsik menghasilkan nilai $\mathrm{P}$ untuk masingmasing variabel sebesar $0,760,0,655,0,771>0,05$, sehingga dapat disimpulkan bahwa semua data yang diuji berdistribusi normal.

Tabel 5. Hasil Uji Lineritas

\begin{tabular}{lccc} 
& $\mathbf{F}$ & $\mathbf{P}$ & Ket. \\
\hline $\mathrm{X} 1 \rightarrow \mathrm{Y}$ & 113,446 & 0,000 & Linear \\
$\mathrm{X} 2 \rightarrow \mathrm{Y}$ & 92,889 & 0,000 & Linear \\
$\mathrm{X} 1 \& \mathrm{X} 2 \rightarrow \mathrm{Y}$ & 73,925 & 0,000 & Linear \\
\hline
\end{tabular}

Berdasarkan uraian dalam tabel di atas, diketahui bahwa nilai $\mathrm{P}$ untuk uji linearitas variabel dukungan sosial dengan prokrastinasi akademik dan motivasi intrinsik dengan prokrastinasi akademik serta dukungan sosial dan motivasi intrinsik dengan prokrastinasi akademik sebesar 0,000, 0,000, 0,000< 0,05, maka dapat disimpulkan bahwa ketiga uji linearitas tersebut memenuhi syarat linearitas.

Tabel 6. Hasil Uji Hipotesis

\begin{tabular}{lccccc}
\hline & $\mathbf{F}$ & $\mathbf{R}$ & $\mathbf{r}^{\mathbf{2}}$ & $\mathbf{P}$ & Ket. \\
\hline $\mathrm{X} 1 \rightarrow \mathrm{Y}$ & 93,578 & 0,756 & 0,572 & 0,000 & Sig. \\
$\mathrm{X} 2 \rightarrow \mathrm{Y}$ & 73,817 & 0,716 & 0,513 & 0,000 & Sig. \\
$\mathrm{X} 1 \& \mathrm{X} 2 \rightarrow \mathrm{Y}$ & 73,925 & 0,826 & 0,682 & 0,000 & Sig. \\
\hline
\end{tabular}

Berdasarkan uraian pada tabel hasil uji hipotesis di atas dapat dijelaskan sbahwa ada hubungan negatif yang signifikan antara dukungan sosial dengan Prokrastinasi Akademik mahasiswa yang ditunjukkan oleh nilai koefesien korelasi (R) antara dukungan sosial dengan prokrastinasi akademik sebesar 0,756 dengan $\mathrm{P}=0,000<0,05$. Hal ini menunjukkan bahwa terjadi hubungan yang kuat antara dukungan sosial dengan prokrastinasi akademik pada mahasiswa jurusan BKPI. Nilai $R 2$ ( $R$ Square) sebesar 0,572 , artinya bahwa persentase sumbangan antara dukungan sosial dengan prokrastinasi akademik adalah sebesar $57,2 \%$

Kemudian ada hubungan negatif yang signifikan antara motivasi intrinsik dengan prokrastinasi akademik mahasiswa yang ditunjukkan oleh nilai koefesien korelasi (R) antara motivasi intrinsik dengan prokrastinasi akademik sebesar 0,716 dengan $\mathrm{P}=0,000<0,05$. Hal ini menunjukkan bahwa terjadi hubungan yang kuat antara motivasi intrinsik dengan prokrastinasi akademik pada mahasiswa Jurusan BKPI. Nilai R2 (R Square) sebesar 0,513, artinya bahwa persentase sumbangan antara kecerdasan emosi dengan perilaku prososial adalah sebesar $51,3 \%$.

Seterusnya ada hubungan negatif yang signifikan antara dukungan sosial dan motivasi intrinsik dengan prokrastinasi akademik mahasiswa yang ditunjukkan oleh nilai koefesien korelasi (R) antara dukungan sosial dan motivasi intrinsik dengan prokrastinasi akademik sebesar 0,826 dengan $\mathrm{P}=0,000$ $<0,05$. Hal ini menunjukkan bahwa terjadi hubungan yang kuat antara dukungan sosial dan motivasi intrinsik dengan prokrastinasi akademik pada mahasiswa jurusan BKPI. Nilai R2 (R Square) sebesar 0,682 , artinya bahwa persentase sumbangan antara dukungan sosial dan motivasi intrinsik dengan prokrastinasi akademik adalah sebesar 68,2\%.

Tabel 7. Hasil Uji Analisis Regresi Berganda

\begin{tabular}{|c|c|c|c|c|}
\hline Variabel & $\begin{array}{c}\text { Koefisien } \\
\text { Regresi (B) }\end{array}$ & $\begin{array}{c}\text { Std } \\
\text { Error }\end{array}$ & $\mathbf{T}$ & Sig \\
\hline Constant & \multicolumn{4}{|l|}{13,238} \\
\hline $\begin{array}{l}\text { Dukungan } \\
\text { Sosial }\end{array}$ & 0,380 & 0,063 & 6,045 & 0,000 \\
\hline $\begin{array}{l}\text { Motivasi } \\
\text { Intrinsik }\end{array}$ & 0,465 & 0,095 & 4,878 & 0,000 \\
\hline $\begin{array}{l}\text { Dari } \\
\text { diperoleh ga } \\
\text { berikut : }\end{array}$ & $\begin{array}{l}\text { gujian pada } \\
\text { ersamaan } \mathrm{re}\end{array}$ & $\begin{array}{l}\text { tabel } \\
\text { grasi }\end{array}$ & $\begin{array}{l}\text { di atas } \\
\text { rganda }\end{array}$ & $\begin{array}{l}\text { maka } \\
\text { ebagai }\end{array}$ \\
\hline
\end{tabular}


Harmalis., Sasferi, N., Naidarti., Juliawati, D., Yandri, $H$. Jurnal Mahasiswa BK An-Nur : Berbeda, Bermakna, Mulia

Volume 7 Nomor 2 Tahun 2021

Tersedia Online: https://ojs.uniska-bjm.ac.id/index.php/AN-NUR

p-ISSN. 2460-9722 | e-ISSN. 2622-8297

Berdasarkan persamaan tersebut dapat dijelaskan bahwa konstanta 13,238 artinya jika nilai dukungan sosial dan motivasi intrinsik mahasiswa adalah tetap atau dapat dikatakan sama dengan nol, maka tingkat prokrastinasi akademik mahasiswa adalah sebesar 13,238.

Nilai dukungan sosial sebesar 0,380 atau $38,0 \%$, artinya jika nilai motivasi intrinsik tetap atau sama dengan nol dan dukungan sosial mengalami kenaikan $1 \%$, maka tingkat prokrastinasi akademik mahasiswa akan mengalami Penurunan sebesar $38,0 \%$. Koefisien bernilai negatif artinya terjadi hubungan yang negatif antara dukungan sosial dengan prokrastinasi akademik, semakin tinggi dukungan sosial mahasiswa, maka semakin menurun prokrastinasi akademiknya.

Nilai motivasi intrinsik sebesar 0,465 atau $46,5 \%$, artinya jika nilai dukungan sosial tetap atau sama dengan nol dan motivasi intrinsik mengalami kenaikan $1 \%$, maka tingkat prokrastinasi akademik mahasiswa akan mengalami peningkatan sebesar $46,5 \%$. Koefisien bernilai negatif artinya terjadi hubungan yang negatif antara motivasi intrinsik dengan prokrastinasi akademik, semakin tinggi motivasi intrinsik mahasiswa, maka semakin menuru prokrastinasi akademiknya

\section{Pembahasan}

Bedasarkan hasil uji hipotesis diketahui bahwa dukungan sosial memiliki hubungan negatif yang signifikan dengan prokrastinasi akademik mahasiswa jurusan BKPI, hal ini bermakna bahwa ada sebagian kelompok mahasiswa jurusan BKPI yang memiliki dukungan social tinggi. Selanjutnya untuk variable prokrastinasi akademik menunjukkan ada sebagian kelompok mahasiswa jurusan BKPI yang memiliki prokrastinasi akademik rendah, hal ini berarti bahwa semakin tinggi tingkat dukungan sosial orang lain (seperti: dosen dan teman) kepada mahasiswa jurusan BKPI, maka akan semakin menurun prokrastinasi akademik mahasiswa tersebut, dan begitu pula sebaliknya semakin rendah tingkat dukungan sosial orang lain (seperti: dosen dan teman) kepada mahasiswa jurusan BKPI, maka akan semakin tinggi pula prokrastinasi akademik mahasiswa tersebut.

Hasil riset lainnya juga menunjukkan salah satu dari faktor eksternal yang dapat mempengaruhi prokrastinasi akademik adalah dukungan sosial seperti dukungan sosial dari orang tua dan dukungan sosial dari teman sebaya. Artinya dukungan sosial dari orang-orang yang berada di sekitar individu memiliki hubungan negatif dengan perilaku prokrastinasi individu terhadap tugasnya (Ghufron, 2003)

Besarnya sumbangan persentase antara dukungan sosial pada prokrastinasi akademik adalah $57,2 \%$, hal ini berarti bahwa dukungan sosial terbukti mampu memberikan kontribusi terhadap prokrastinasi akademik mahasiswa jurusan BKPI. Faktor-faktor dukungan sosial yang dapat mempengaruhi prokrastinasi akademik mahasiswa jurusan BKPI yaitu nilai-nilai sosial yang terinternalisasi di dalam diri mahasiswa, dan rasa empati terhadap orang lain. Hal ini sejalan dengan pernyataan Myers sedikitnya ada tiga faktor penting yang mendorong seseorang untuk memberikan dukungan yang positif, diantaranya : 1). empati, 2). norma dan nilai sosial, 3). pertukaran sosial (Maslihah, 2011). Keseimbangan dalam pertukaran akan menghasilkan kondisi hubungan interpersonal yang memuaskan. Pengalaman akan pertukaran secara timbal balik ini membuat individu lebih percaya bahwa orang lain akan menyediakan.

Secara umum dari hasil uji frekuensi responden berdasarkan variabel dukungan sosial diketahui bahwa mahasiswa jurusan BKPI memiliki tingkat dukungan sosial dan prokrastinasi akademik tetapi berada pada ketegori sedang, namum hasil penelitian juga menunjukkan bahwa ada $25,0 \%$ mahasiswa memiliki dukungan social tunggi seperti menghargai dan memberi semangat kepada temannya sehingga dapat menurunkan prokrastinasi akademik ketika berinteraksi di lingkungan kampus.

Bedasarkan hasil uji hipotesis diketahui bahwa motivasi intrinsik memiliki hubungan negatif yang signifikan dengan prokrastinasi akademik mahasiswa jurusan BKPI. Artinya ada sebagian kelompok mahasiswa jurusan BKPI yang memiliki prokrastinasi akademik rendah. Hal ini menunjukkan bahwa semakin tinggi tingkat motivasi intrinsik mahasiswa jurusan BKPI, maka akan semakin menurun prokrastinasi akademik mahasiswa tersebut. Sejalan dengan perndapat Green mengatakan bahwa salah satu faktor internal (psikologis) yang dapat mempengaruhi prokrastinasi akademik adalah motivasi intrinsik (Ghufron \& Risnawati, 2010).

Besarnya sumbangan persentase antara motivasi intrinsik dengan prokrastinasi akademik adalah sebesar 51,3\%. Hasil penelitian ini memberikan makna bahwa motivasi intrinsik terbukti mampu memberikan kontribusi terhadap prokrastinasi akademik mahasiswa jurusan BKPI. Hal ini sejalan dengan hasil penelitian terdahulu yang meneliti 
Harmalis., Sasferi, N., Naidarti., Juliawati, D., Yandri, $H$. Jurnal Mahasiswa BK An-Nur : Berbeda, Bermakna, Mulia

Volume 7 Nomor 2 Tahun 2021

Tersedia Online: https://ojs.uniska-bjm.ac.id/index.php/AN-NUR

p-ISSN. 2460-9722 | e-ISSN. 2622-8297

hubungan antara motivasi intrinsik dengan prokrastinasi akademik mahasiswa aktivis universitas Negeri Makassar, diketahui bahwa sumbangan efektif atau $\mathrm{r}$ square sebesar $37,5 \%$ perilaku prokrastinasi akademik mahasiswa aktivis dipengaruhi oleh faktor motivasi intrinsik (Fauziah, 2011)

Bedasarkan hasil uji hipotesis diketahui bahwa dukungan sosial dan motivasi intrinsik secara bersama memiliki hubungan negatif yang signifikan dengan prokrastinasi akademik mahasiswa jurusan BKPI. Berdasarkan perbandingan ini bermakna bahwa ada sebagian kelompok mahasiswa berada dalam kategori rendah, artinya semakin tinggi tingkat dukungan sosial dan motivasi intrinsik mahasiswa jurusan BKPI, maka akan semakin menurun tingkat prokrastinasi akademik mahasiswa, dan bergitu pula sebaliknya semakin menurun tingkat dukungan sosial dan mativasi intrinsik, maka semakin meningkat prokrastinasi akademik mahasiswa pada jurusan BKPI tersebut. Hal ini sejalan dengan hasil penelitian terdahulu yang meneliti tentang prokrastinasi akademik dan dukungan sosial teman sebaya pada mahasiswa fakultas psikologi Universitas Katolik Widya Mandala Surabaya yang menunjukkan ada hubungan antara prokrastinasi akademik dan dukungan sosial teman sebaya pada mahasiswa Fakultas Psikologi Universitas Katolik Widya Mandala Surabaya (Pradinata \& Susilo, 2016).

\section{PENUTUP}

Simpulan dari penelitian ini menunjukkan adanya hubungan negatif yang signifikan antara dukungan sosial dengan prokrastinasi akademik mahasiswa. Kemudian adanya hubungan negatif yang signifikan antara motivasi intrinsik dengan prokrastinasi akademik mahasiswa. Selanjutnya terdapat hubungan negatif yang signifikan antara dukungan sosial dan motivasi intrinsik dengan prokrastinasi akademik mahasiswa. Hal ini berarti, semakin tinggi tingkat dukungan sosal dan motivasi intrinsik yang dimiliki mahasiswa, maka semakin menurun prokrastinasi akademik pada mahasiswa.

\section{REFERENSI}

Arikunto, S. (2010). Prosedur Penelitian Suatu Pendekatan Praktik. Jakarta: Rineka Cipta.

Azwar, S. (2016). Penyusunan Skala Psikologi, Yogyakarta: Putaka Pelajar.

Chaplin, J. P. (2002), Kamus lengkap Psikologi. Jakarta.:Raja Grafindo Persada
Djamarah, S. B. (2002). Psikologi Belajar. Jakarta: Rineka Cipta

Elliot, A. J., Faler, J., McGregor, H. A., Campbell, W. K., Sedikides, C., \& Harackiewicz, J. M. (2000). Competence valuation as a strategic intrinsic motivation process. Personality and Social Psychology Bulletin, 26(7), 780-794

Faiz, A., Yandri, H., Kadafi, A., Mulyani, R. R., Nofrita, N., \& Juliawati, D. (2019). Pendekatan Tazkiyatun An-Nafs untuk membantu mengurangi emosi negatif klien. Counsellia: Jurnal Bimbingan dan Konseling, 9(1), 65-78. http://doi.org/10.25273/counsellia.v9i1.4300

Fausiah, N. L. (2011). Hubungan Motivasi Intrinsik dengan Prokrastinasi Akademik pada Mahasiswa Aktivis Universitas Negeri Makassar (Doctoral dissertation, Universitas Negeri Mkassar).

Ferrari, J. R. (1991). Self-handicapping by procrastinators: Protecting self-esteem, socialesteem, or both?. Journal of Research in Personality, 25(3), 245-261.

Ferrari, J. R., Johnson, J. L., \& McCown, W. G. (1995). Procrastination and task avoidance: Theory, research, and treatment. New York: Springer Science \& Business Media.

Ghufron, M. N \& Risnawati R. S. (2010). Teori-Teori Psikologi. Jakarta: Ar-Ruzz Media

Ghufron, M. N. (2003). Hubungan kontrol diri dan persepsi remaja terhadap Penerapan disiplin orangtua dengan Prokrastinasi akademik (Doctoral dissertation, [Yogyakarta]: Universitas Gadjah Mada).

Hamalik, O. (1992). Psikologi Belajar dan Mengajar. Bandung: Sinar Baru.

Juliawati, D. (2014). Efektifitas layanan bimbingan kelompok untuk mengurangi prokrastinasi akademik siswa. In Proceedings of International Guidance and Counseling Conference. Retrieved from https://www. researchgate. net/publication/327915616_EFEKTIVITAS_LA YANAN_BIMBINGAN_KELOMPOK_MENG URANGI_PROKRASTINASI_AKADEMIK_SI SWA.

Juliawati, D. (2017). Studi Kasus Terhadap Mahasiswa yang Menikah Saat Menempuh Masa Kuliah. Tarbawi: Jurnal Ilmu Pendidikan, 13(2), 43-49.

Juliawati, D., \& Yandri, H. (2018). Prokrastinasi Akademik Mahasantri Ma'had Al Jami'ah IAIN 
Harmalis., Sasferi, N., Naidarti., Juliawati, D., Yandri, $H$. Jurnal Mahasiswa BK An-Nur : Berbeda, Bermakna, Mulia

Volume 7 Nomor 2 Tahun 2021

Tersedia Online: https://ojs.uniska-bjm.ac.id/index.php/AN-NUR p-ISSN. 2460-9722 | e-ISSN. 2622-8297

Kerinci. Jurnal Fokus Konseling, 4(1), 19-26. https://doi.org/10.26638/jfk.485.2099

Kumalasari, F., \& Ahyani, L. N. (2012). Hubungan antara dukungan sosial dengan penyesuaian diri remaja di panti asuhan. Jurnal Psikologi: PITUTUR, 1(1), 19-28.

Marni, A., \& Yuniawati, R. (2015). Hubungan antara dukungan sosial dengan penerimaan diri pada lansia di panti wredha budhi dharma yogyakarta (Doctoral dissertation, Universitas Ahmad Dahlan).

Maslihah, S. (2011). Studi tentang hubungan dukungan sosial, penyesuaian sosial di lingkungan sekolah dan prestasi akademik siswa SMPIT Assyfa Boarding School Subang Jawa Barat. Jurnal Psikologi, 10(2), 103-114.

Nitami, M., Daharnis, D., \& Yusri, Y. (2015). Hubungan motivasi belajar dengan prokrastinasi akademik siswa. Konselor, 4(1), 1-12.

Pradinata, S., \& Susilo, J. D. (2016). Prokrastinasi Akademik dan Dukungan Sosial Teman Sebaya pada Mahasiswa Fakultas Psikologi Universitas Katolik Widya Mandala Surabaya. Experientia, 4(2), 85-95.

Rizvi, A., Prawitasari, J. E., \& Soetjipto, H. P. (1997). Pusat kendali dan efikasi-diri sebagai prediktor terhadap prokrastinasi akademik mahasiswa. Psikologika: Jurnal Pemikiran dan Penelitian Psikologi, 2(3), 51-66.

Sarafino, E. P. (1998). Health Pschology : Biopsychosocial Interactions. New York: United State of Amarica.

Sartika, M., \& Yandri, H. (2019). Pengaruh layanan bimbingan kelompok terhadap konformitas teman sebaya. Indonesian Journal of Counseling and Development, 1(1), 9-17.

Steel, P. (2007). The nature of procrastination: a metaanalytic and theoretical review of quintessential self-regulatory failure. Psychological bulletin, 133(1), 65.

Suryabrata, S. (2005). Pengembangan Alat Ukur Psikologi. Yogykarta: Andi Offset.

Ulandari, Y., \& Juliawati, D. (2019). Pemanfaatan layanan bimbingan kelompok untuk meningkatkan kecerdasan emosi siswa. Indonesian Journal of Counseling and Development, 1(1), 1-8.

Wiyarti, H. A., \& Setyawan, I. (2018). Hubungan antara dukungan sosial teman sebaya dengan prokrastinasi menghafal al-qur'an pada santri di pondok pesantren modern islam assalaam surakarta. Empati, 6(4), 33-36.

Yandri, H., \& Juliawati, D. (2018). Profile of the problem of the adolescent with parents as Indonesian migrant workers. Konselor, 7(4), 160-165.

https://doi.org/10.24036/0201874101452-0-00 